\title{
Subfossil Land Snails from Easter Island, Including Hotumatua anakenana, New Genus and Species (Pulmonata: Achatinellidae) ${ }^{1}$
}

\author{
Patrick V. Kirch, ${ }^{2,3}$ Carl C. Christensen, ${ }^{4}$ and David W. Steadman ${ }^{5}$
}

\begin{abstract}
The depauperate modern terrestrial biota of Easter Island contrasts with that of most other southeastern Polynesian high islands, which characteristically support a number of endemic species of insects, land snails, birds, and plants. We investigated cultural and noncultural late Holocene deposits at Anakena, Easter Island, establishing the former presence of endemic land snails on the island. These include an unidentified helicinid, a Nesopupa species, and a previously undescribed extinct achatinellid land snail, Hotumatua anakenana Kirch, Christensen \& Steadman, n. genus and n. sp. A human-introduced achatinellid, Pacificella variabilis, occurs in later stratigraphic contexts of the same site. Prehistoric deforestation may have been the primary cause of the extinction of Hotumatua, although predation by rats or other alien species may have been involved as well. Along with recently discovered extirpated species of angiosperms, seabirds, and land birds, the extinction of Hotumatua reflects the nearly complete loss of the native biota of Easter Island after Polynesian colonization about 1,000 yr ago.
\end{abstract}

Easter Island (Rapa Nui, Isla de Pascua, $27^{\circ} 09^{\prime} \mathrm{S}, 109^{\circ} 25^{\prime} \mathrm{W}$ ), the most southeasterly island to be colonized prehistorically by Polynesians, is also something of a biogeographical enigma. The known terrestrial biota of Easter Island is noteworthy for the scarcity or absence of endemic species of flowering plants, invertebrates, and vertebrates. The only surviving endemic plants are three species of grasses and the small leguminous tree Sophora toromiro Skottsberg, the last of which exists only in botanic gardens (Bahn and

\footnotetext{
${ }^{1}$ Financial support was provided by the Instituto de Estudios de Isla de Pascua, Universidad de Chile (Santiago) to P.V.K. and NSF grants BNS-9020750 (to P.V.K. and D.W.S) and EAR-9714819 (to D.W.S.). Manuscript accepted 19 February 2008.

${ }^{2}$ Corresponding author.

${ }^{3}$ Departments of Anthropology and Integrative Biology, University of California, Berkeley, California 94720.

${ }^{4}$ William S. Richardson School of Law, University of Hawai'i, Honolulu, Hawai'i 96822, and Bernice P. Bishop Museum, Honolulu, Hawai'i 96817.

${ }^{5}$ Florida Museum of Natural History, University of Florida, Gainesville, Florida 32611.
}

Pacific Science (2009), vol. 63, no. 1:105-122

(C) 2009 by University of Hawai'i Press

All rights reserved
Flenley 1992). No surely indigenous or endemic land snails, a key component of eastern Pacific faunas, have been reported previously from Easter Island. Just four of the island's 35 species of insects are endemic, these including one endemic genus of Diptera (Skottsberg 1956). Of the 14 recorded species of Lepidoptera, two or fewer species are indigenous and none is endemic (Holloway 1990). No native species of land birds occur today on Easter Island (Johnson et al. 1970, Steadman 1995).

The extreme geographic isolation of Easter Island undoubtedly contributed to this limited terrestrial biota, but this factor alone cannot explain the apparent scarcity of endemic taxa. Indeed, extensive archaeological and paleoecological research over the past three decades has shown that Easter Island had a formerly more diverse biota, including forests inhabited by endemic species of plants and animals, which were destroyed by the impact of intensive land use by prehistoric Polynesians. The past forest communities of Easter Island have been disclosed by palynological studies of the island's three crater lakes (Flenley 1979, Dransfield et al. 1984, Flenley and King 1984, Flenley et al. 1991, Bahn and Flenley 1992, Flenley and Bahn 


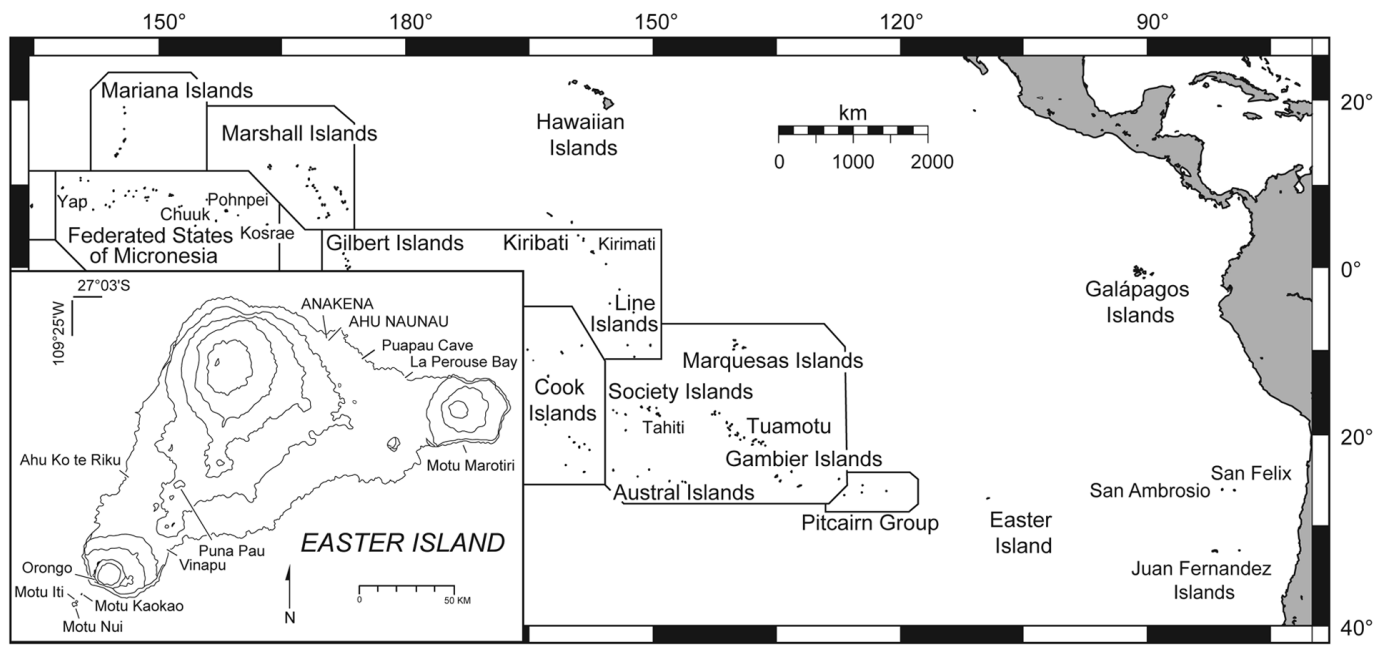

FIgURe 1. The southeastern Pacific Ocean, showing the locations of island groups discussed in the text. Inset shows Easter Island and the location of Anakena Bay.

2002). The most prominent tree represented in the pollen spectra was the extinct endemic palm Paschalococos disperta Dransfield (in Zizka 1991), believed to be related to the Chilean oil-palm, Jubaea chilensis (Molina) Baillon. The Easter Island palm is well represented by pollen in the sediment cores, as well as by seed endocarps recovered from dry caves (Dransfield et al. 1984). The palynological record documents deforestation of Easter Island "probably over a considerable time span, but since $990 \pm 70 \mathrm{yr}$ BP at Rano Kao" (Flenley and King 1984:50); that is, in the period following Polynesian colonization.

The former existence of an indigenous terrestrial fauna, including land snails, before the deforestation of Easter Island is also supported by faunal comparison of Easter Island with other volcanic "high" islands of the eastern Pacific (Figure 1) (Table 1). Rapa (in the Austral Islands, ca. 3,500 km west of Easter Island), with only $25 \%$ of Easter Island's

TABLE 1

Approximate Number of Endemic Species in the Terrestrial Biotas of Selected High Islands in the Southeastern Pacific Ocean

\begin{tabular}{lrrrr}
\hline \hline Parameter & Easter & Rapa & Henderson & Juan Fernández \\
\hline Angiosperms & 4 & 70 & 6 & 101 \\
Insects & 4 & 200 & 10 & 235 \\
Land snails & $0 / 1-4$ & 100 & 7 & 35 \\
Land birds & $0 / 5$ & 1 & $4 / 9$ & 3 \\
Island area $\left(\mathrm{km}^{2}\right)$ & 161 & 22 & 37 & 148 \\
Island elevation (m) & 507 & 633 & 185 & $\sim 1,000$ \\
Isolation $(\mathrm{km})$ from nearest & 1,760 & 490 & & 670 \\
$\quad$ high island or continent & & & &
\end{tabular}

Note: Where two numbers are given, the first includes extinct species recorded from Holocene archaeological and paleontological sites. See text for more details. 
land area, has a land snail fauna comprising approximately 100 species, with endemic genera or species in the families Assimineidae, Achatinellidae, Endodontidae, Partulidae, and Helicarionidae, as well as indigenous or possibly endemic species of Hydrocenidae, Helicinidae, and Pupillidae (Cooke and Kondo 1960, Solem 1973, 1976; materials in Bernice P. Bishop Museum collection). The Mangareva (Gambier) Islands to the northeast of Rapa, although like Easter Island heavily deforested and eroded, are noteworthy for a rich fossil land snail fauna including six endemic species or subspecies of the genus Tubuaia (Achatinellidae), three endemic genera (Anceyodonta, Rikitea, and Gambiodonta) and 24 endemic species in the Endodontidae, one endemic punctid, two endemic species in the Helicarionidae, and two endemic species in the Assimineidae (Cooke 1935, Kondo 1962, Solem 1976, Abdou and Bouchet 2000, Bouchet and Abdou 2001, 2003, Conte and Kirch 2004). Henderson Island $(1,930 \mathrm{~km}$ west of Easter Island) includes at least seven indigenous or endemic species of Achatinellidae, Endodontidae, Helicarionidae, Hydrocenidae, Helicinidae, and Pupillidae (Preece 1995). East of Polynesia, the Juan Fernández Islands are inhabited by 40 indigenous species of land snails, 35 of which are endemic (including genera of Achatinellidae and Charopidae, and species of Punctidae and Succineidae) (Odhner 1922, Cooke and Kondo 1960, Solem 1983). Isla San Ambrosio is inhabited by an endemic genus and species of Achatinellidae (Odhner 1963). The presence of endemic land snails on all of these islands both west and east of Easter Island makes the apparent absence of endemic taxa on the latter especially anomalous.

In this paper we document the prehistoric loss of an endemic genus and species of achatinellid land snail on Easter Island, as well as the prehistoric presence of another achatinellid presumably introduced by the Polynesians. This adds to the evidence that the island once supported a much richer terrestrial biota, including at least five taxa of land birds and 24 species of seabirds (Steadman 1995, 2006).

\section{Review of Easter Island Nonmarine Mollusks}

As reported by Dall (1908), Odhner (1922), Waldén (1961), Naranjo-Garcia and Appleton (1998), and Boyko and Cordeiro (2001), the known terrestrial mollusk fauna of Easter Island consists of three alien slugs, Milax gagates (Draparanaud, 1801), Lebmannia valentiana (Férussac, 1822) (formerly placed in the genus Limax), Deroceras reticulatum (Müller, 1774); the European garden snail, Cornu aspersum (Müller, 1774) (formerly Helix aspersa); and two smaller species of snails, the subulinid Allopeas gracile (Hutton, 1834) (formerly placed in the genus Lamellaxis), and the achatinellid Pacificella variabilis Odhner, 1922. Both Allopeas gracile and Pacificella variabilis are widely distributed, the former now circumtropical (Preece 1995, Boyko and Cordeiro 2001). Allopeas gracile is commonly found in Polynesian archaeological sites of precontact age (Christensen and Kirch 1981, 1986, Rolett 1992), and Pacificella variabilis, although described from Easter Island material, also is widely distributed in the Pacific Islands as a result of human dispersal (Cooke and Kondo 1960).

Unpublished records in the malacological collection of the Bernice P. Bishop Museum (врвм) add three additional alien species to the Easter Island nonmarine snail fauna. The first is Gastrocopta servilis (Gould, 1843), based on specimen врвм 163205 (ex. California Academy of Sciences 28235; $\frac{1}{2}$ mile inland, Hangaroa, Easter Island; Templeton Crocker Expedition). The second is Paralaoma servilis (Shuttleworth, 1852), based on врвм 207577, Easter Island, I. McT. Cowan, 1965 (see Roth 1986, 1987, Falkner et al. 2002). The third is Allopeas clavulinum (Potiez \& Michaud, 1838), based on врвм 207576, Mautini, Easter Island, I. McT. Cowan, 1965. Each of these species was undoubtedly introduced since European contact.

In the Pacific, the family-level diversity of land snails diminishes eastward from Melanesia through eastern Polynesia (Solem 1959, 1973). At the southeastern terminus of this region, Easter would be expected to have a land snail fauna of low family-level diversity. 


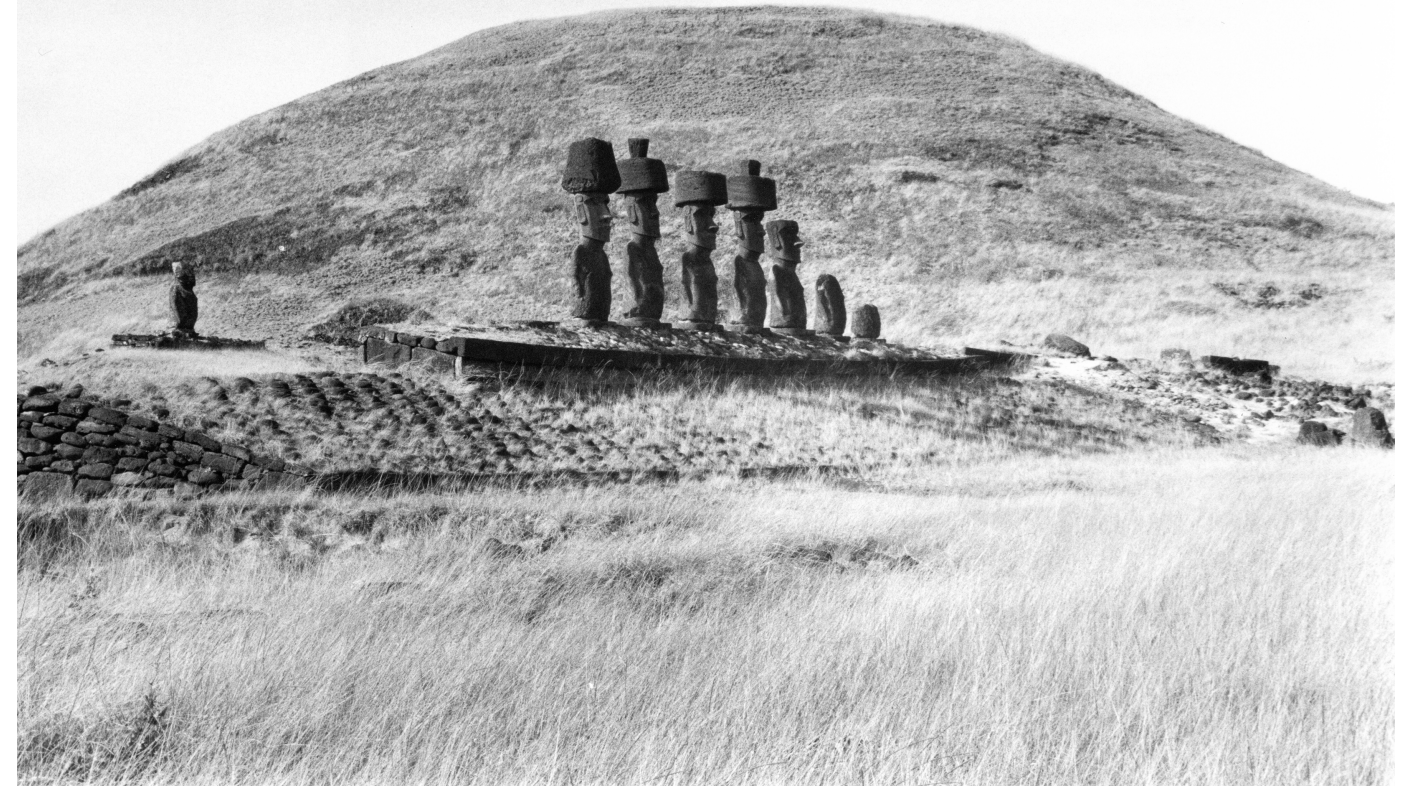

Figure 2. View of Ahu Naunau temple at Anakena, after excavation and reerection of the statues. The grassy vegetation typifies Easter Island today. (Photo by P.V.K., 14 September 1984.)

The Endodontidae (in the restricted sense of Solem [1976]), Amastridae, and Partulidae, unusual among family-level taxa of land animals in that they inhabit the islands of the Pacific but are virtually absent from the surrounding continents (Solem 1981), could have been present on Easter Island. In addition to these, some species of Achatinellidae could be expected to have occurred on Easter, as this family is almost always represented on high islands in the eastern Pacific. Off the coast of the Americas, endemic achatinellids inhabit the Revillagigedos, the Galápagos, San Ambrosio Island in the Desventuradas, and the Juan Fernández Islands, yet no members of the family have been reported from the American mainland. The family reaches its greatest levels of diversity in Hawai'i (eight genera, 152 species), the Austral Islands (11 genera, 35 species), and Juan Fernández (Odhner 1922, Cooke and Kondo 1960,
Chambers 1991, Cowie et al. 1995). Some species have been transported by humans within this region, either prehistorically or during the modern era (Cooke and Kondo 1960, Christensen and Kirch 1981, 1986), and Solem (1981) suggested that the presence of small achatinellids at the limits of the family's range may be a result of human transport.

\section{MATERIALS AND METHODS}

We explored Easter Island for Holocene sediments that might contain shells of endemic mollusks in 1984 (P.V.K.) and 1991 (D.W.S.). Except possibly for the lacustrine deposits in the island's three volcanic craters (see Flenley et al. 1991), the Easter Island landscape offers limited opportunities for the accumulation of sediments (such as dunes, colluvium, or alluvium) that would preserve 


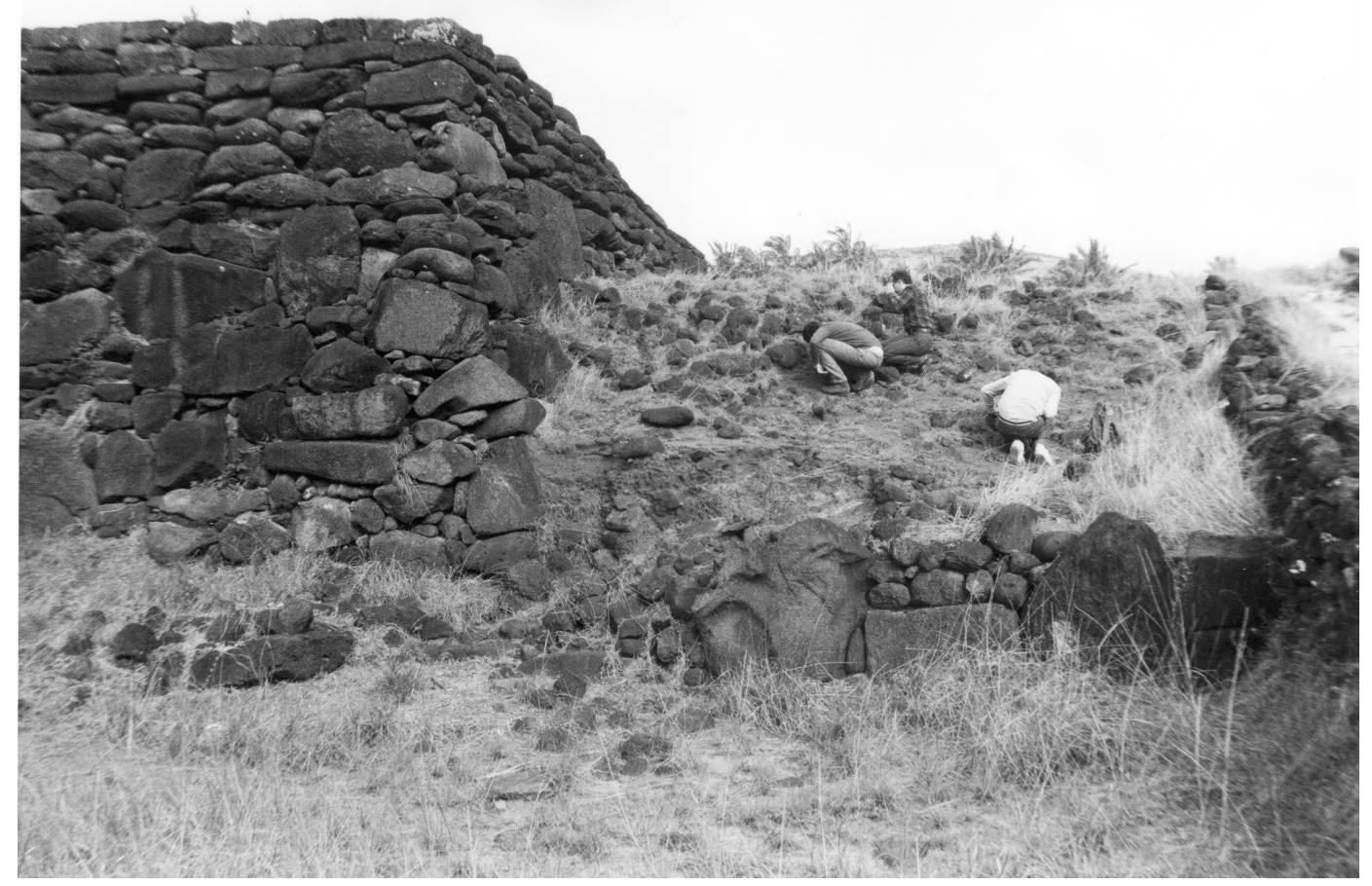

Figure 3. Locality 1, a series of fine clay-silt lenses abutting the Ahu Naunau temple platform. The thick deposit of calcareous dune sand formerly covering this area was removed during archaeological excavation in 1978. (Photo by P.V.K., 14 September 1984.)

the shells of terrestrial mollusks. An exception is the valley mouth at Anakena on the leeward north coast, where several low ridges and cinder cones enclose the largest and most protected of the few calcareous sand beaches on the island. In a zone extending ca. $200 \mathrm{~m}$ inland from the shoreline at Anakena, terrigenous alluvial deposits are interleaved with aeolian calcareous sands. We collected terrestrial mollusks from three stratigraphic contexts within this zone, as described here.

\section{Anakena Locality 1}

The first sample was obtained from terrigenous deposits that abut the large archaeological temple site at Ahu Naunau (Figure 2). Ahu Naunau was partially excavated and restored in 1978-1979 by Sergio Rapu (pers. comm., 1984), who removed a substantial de- posit of aeolian sand overlying and abutting the north wall of the temple, including a massive deposit of reddish brown clay/silt lenses that lie against one of the earlier architectural platforms (Figure 3). Prehistoric construction of the temple platform at Ahu Naunau created an artificial sediment trap on its inland (southern) side for terrigenous materials eroding from the volcanic slopes a short distance inland. The fine sediments exposed on the western side of the temple platform resulted from overflow from this sediment trap. The thin lensing of these sediments suggests that deposition took place as a series of discrete overflow events, probably associated with heavy rainfall. The stratigraphic relationship of the deposits to the temple architecture indicates that the sediments were deposited after the initial phases of temple construction. 
Major stratigraphic excavations were conducted within $10 \mathrm{~m}$ of Locality 1 during 1986-1988 by Skjolsvold (1994). The $24{ }^{14} \mathrm{C}$ dates from Anakena reported by Skjolsvold (1994:106) vary from $200 \pm 80$ to $1,170 \pm$ 140 yr B.P. (radiocarbon years before present), with most from ca. 500 to $800 \mathrm{yr}$ B.P. Based on the islandwide cultural sequence and chronology established through excavation of this and comparable sites, the snailbearing deposits at Locality 1 probably date to the Ahu Moai Phase, ca. 1000-1500 A.D. (Kirch 1984:269-274). Stratigraphic correlation with ${ }^{14} \mathrm{C}$-dated deposits at Locality 3 (described in a later section) suggest that the snail-bearing deposits at Locality 1 are prehistoric (older than 1700 A.D.) but younger than $1300+80$ A.D.

Terrestrial mollusks were scattered in low frequency throughout the silt/clay sequence at Locality 1. All of these proved to be of Pacificella variabilis, a species believed to have been dispersed accidentally by prehistoric Polynesian voyagers (Pilsbry and Cooke 1933). Its presence at Locality 1 confirms transport to Easter Island in prehistoric times. No endemic mollusks were found at Locality 1.

\section{Anakena Locality 2}

This site is an erosional gully with intermittent stream flow that extends from south to north through the sand dunes in the lower, central part of Anakena Valley, terminating on the sand beach (Figure 4). Near the mouth of the gully is an alluvial deposit of dark brown silty clay with imbricated volcanic

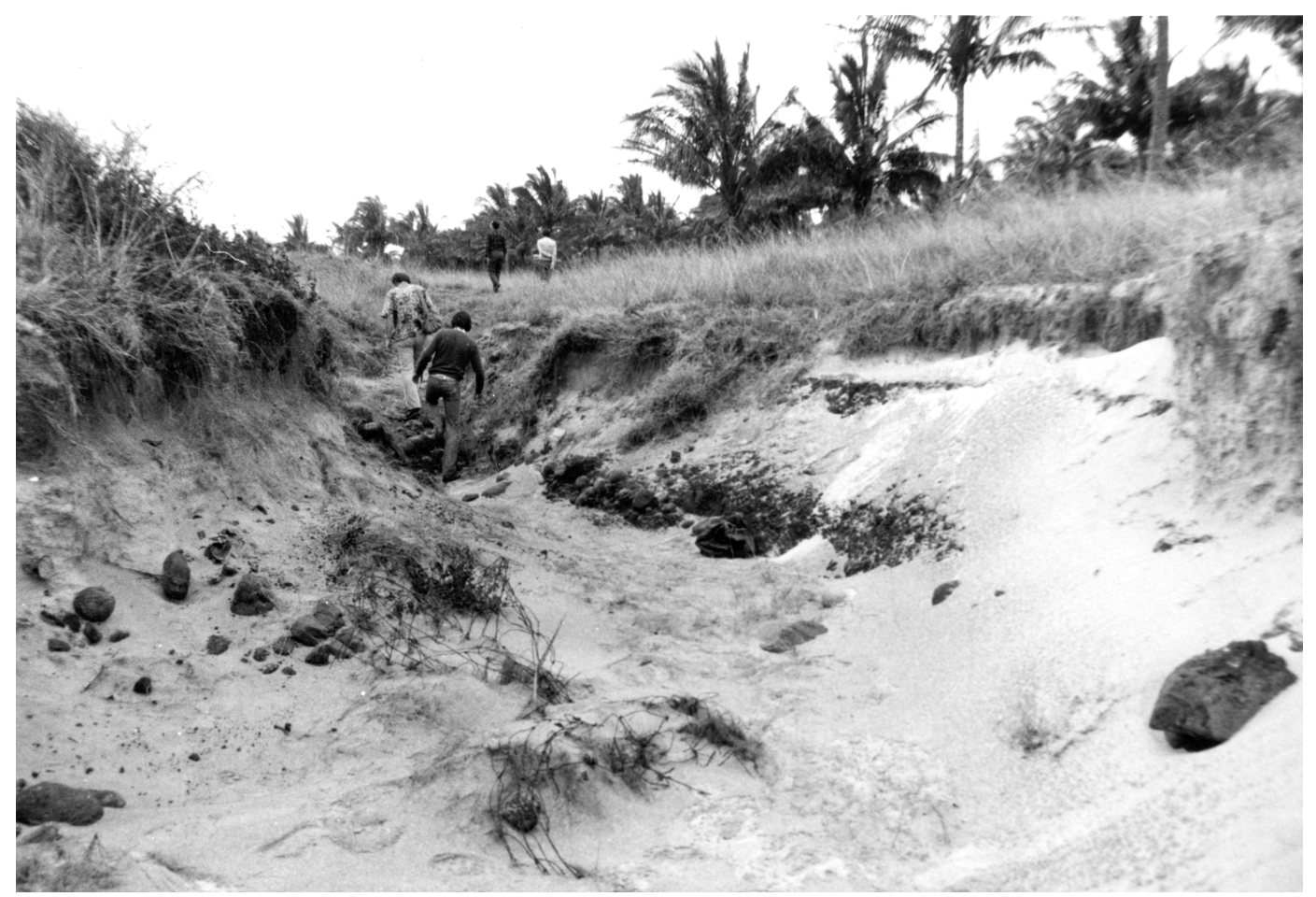

FIgURE 4. Locality 2, an erosional gully extending inland from the beach at Anakena Bay. The thick terrigenous deposit containing shells of extinct Hotumatua anakenana is visible along the base of the gully. (Photo by P.V.K., 14 September 1984.) 
TABLE 2

Stratigraphy and Land Snail Fauna from Locality 2, Anakena, Easter Island, Based on Sediment Samples Collected on 24 July 1991

\begin{tabular}{|c|c|c|c|c|c|c|c|}
\hline $\begin{array}{l}\text { Sample } \\
\text { No. }\end{array}$ & $\begin{array}{l}\text { Volume } \\
\left(\mathrm{cm}^{3}\right)\end{array}$ & $\begin{array}{l}\text { DBD } \\
(\mathrm{cm})\end{array}$ & Sediment Type & Color (moist) & $\mathrm{Ha}$ & $\mathrm{Pv}$ & Gs \\
\hline 1 & 140 & $9-15$ & Med calc sand & 7.5 YR $5 / 4$ brown & - & $\mathrm{C}$ & - \\
\hline 2 & 150 & $18-24$ & " & " & - & $\mathrm{C}$ & - \\
\hline 3 & 160 & $27-31$ & $"$ & 10YR 5/3 brown & - & - & $\mathrm{R}$ \\
\hline 4 & 175 & $34-40$ & $"$ & 10YR $6 / 3$ pale brown & - & $\mathrm{R}$ & - \\
\hline 5 & 185 & $43-49$ & $"$ & " & - & $\mathrm{R}$ & - \\
\hline 6 & 210 & $52-57$ & Med to coarse calc sand & $"$ & - & $\mathrm{R}$ & - \\
\hline 7 & 210 & $61-67$ & Sl pebbly, coarse calc sand & $10 Y R 7 / 3$ very pale brown & - & - & - \\
\hline 8 & 140 & $67-73$ & Sandy, sl silty clay & 5YR $3 / 4$ dark reddish brown & - & - & - \\
\hline 9 & 155 & $76-82$ & Pebbly, sl sandy, sl silty clay & 7.5YR 3/4 dark brown & - & - & - \\
\hline 10 & 100 & $85-91$ & & 5YR $3 / 3$ dark reddish brown & - & - & - \\
\hline 11 & 110 & $94-100$ & Sl pebbly, sl sandy, sl silty, clay & 5YR $3 / 4$ dark reddish brown & - & - & - \\
\hline 12 & 130 & $103-109$ & Sl sandy, sl silty, clay & " & - & - & - \\
\hline
\end{tabular}

Note: Each sample was processed in the laboratory through a nested set of five standard sieves of mesh sizes 12.5, 5.6, 2.0, 1.19, and $0.60 \mathrm{~mm}$. Abbreviations: calc, calcareous; DBD, depth below datum; med, medium grained; sl, slightly. Color data follow the Munsell Soil Color Charts. Snail abundance categories: C, common (5-20); R, rare (<5). Ha, Hotumatua anakenana; Pv, Pacificella variabilis; Gs, Gastrocopta servilis.

cobbles, overlain by 1-2 m of calcareous aeolian sand. Near the top of the sandy unit is a thick $(20-30 \mathrm{~cm})$ paleosol suggesting a substantial period of dune stability. In September 1984, P.V.K. found small numbers of an extinct achatinellid snail that we describe here distributed throughout the basal clay; these were evidently carried with the clay during its alluvial transport from the volcanic slopes surrounding Anakena Valley. Examination of the basal clay for charcoal that might yield a ${ }^{14} \mathrm{C}$ age determination was fruitless.

Later field observations at Locality 2 by D.W.S. (24 July 1991) were in the same gully, but probably 10-20 m north of where P.V.K. had examined these sediments. Details of stratigraphy and the presence of land snails are given in Table 2. Land snail shells were present only in the upper six sample units and consisted primarily of the Polynesianintroduced Pacificella variabilis, and in sample unit 3 a few specimens of the Europeanintroduced Gastrocopta servilis. The absence of any endemic archatinellids in the lower part of the sediment column may be due to the fact that in the section sampled and mapped by D.W.S. (Figure 5) the paleosol had thinned to only $3 \mathrm{~cm}$ on the southwest corner and $1 \mathrm{~cm}$ on the northwest corner.

The dune sand overlying the Locality 2 paleosol may correlate with the sand overburden removed by Rapu at Locality 1 . This would establish the dune deposit under the paleosol in Locality 2 as possibly coeval with the clay/silt-aeolian sand lenses at Locality 1, with the basal clay stratum at Locality 2 being still older. This suggests that the molluscan assemblage from Locality 2 (Table 2) may predate that from Locality 1 . This relative chronology was confirmed through excavation and ${ }^{14} \mathrm{C}$ dating of Locality 3 by D.W.S. in 1991 (see next section).

\section{Anakena Locality 3}

In 1991, D.W.S. excavated a 1 by $4 \mathrm{~m}$ trench on the seaward (northwest) side of Ahu Naunau at Anakena, about $20 \mathrm{~m}$ NNE of Locality 1 and $55 \mathrm{~m}$ west of Locality 2 (Figure 6 [Steadman et al. 1994; Martinsson-Wallin and Crockford (2001) also described this site]). All sediments at Locality 3 underlie the aeolian sands excavated by Rapu in 19781979. The stratigraphy of Locality 3 (Stead- 


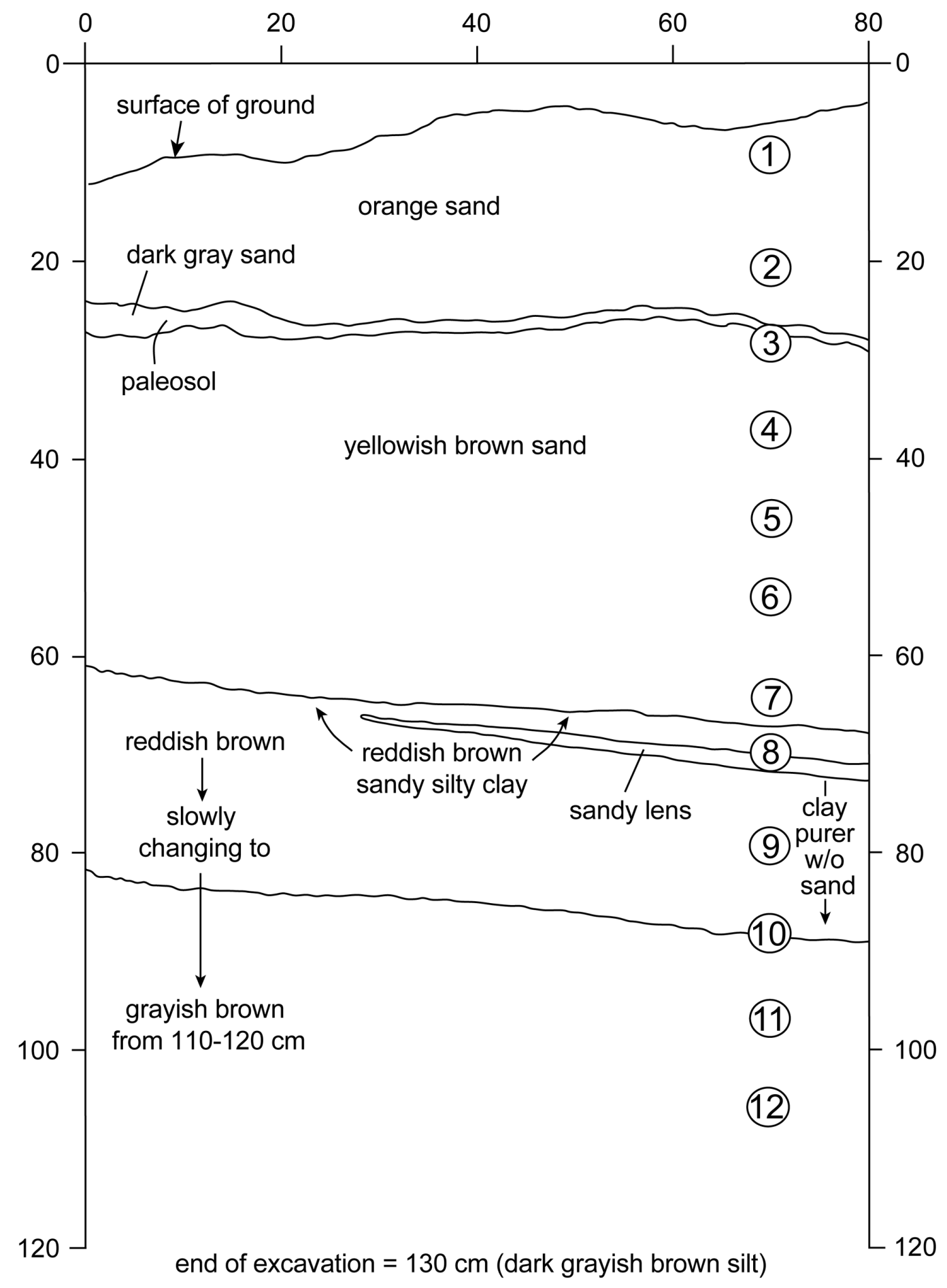

FIGURE 5. Stratigraphic profile of sediments at Locality 2, showing location of sediment samples bearing land snails listed in Table 2. (Mapped by D.W.S., 24 July 1991.) 


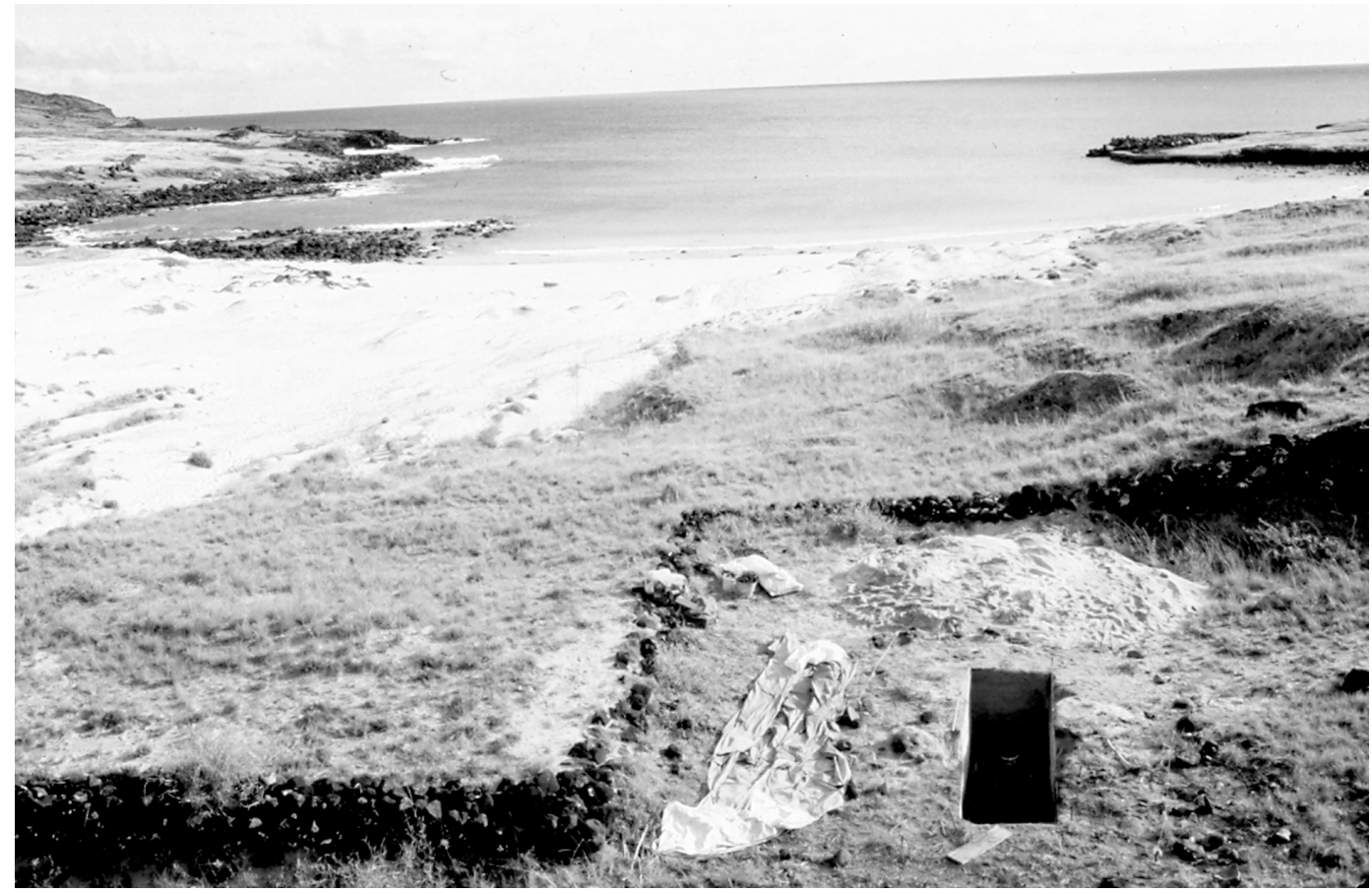

Figure 6. Locality 3. (Photo by D.W.S., 13 July 1991.)

man et al. 1994) (Table 3, Figure 7) consists of three primary units: an upper sandy paleosol (Layer I), dated at $660 \pm 80 \mathrm{yr}$ B.P. at depth 10-20 cm; an inorganic calcareous sand (Layer II), dated at $860 \pm 100$ yr B.P. at depth $37 / 40-57 / 60 \mathrm{~cm}$; and a basal gravelly, sandy, silty clay (Layer III). A hearth at the contact of Layers II and III is dated at $900 \pm 80$ yr B.P. (depth $129-130 \mathrm{~cm}$ ) and $900 \pm 60$ yr B.P. (depth $128-132 \mathrm{~cm}$ ). The four ${ }^{14} \mathrm{C}$ dates are on wood charcoal, corrected for ${ }^{12} \mathrm{C} /{ }^{13} \mathrm{C}$. Calibrated to a calendric time scale, these determinations vary (at $2 \sigma$ ) from 1220-1430 cal A.D. (Layer I) to 1000$1280 \mathrm{cal}$ A.D. (contact of Layers II and III).

Layer I at Locality 3 is believed to correlate with the paleosol at Locality 2. Similarly, the aeolian sands and basal silty clays at both localities probably are stratigraphic equivalents. The extinct achatinellid land snail described here was present in 11 of the 17 sediment samples at Locality 3, as high as Sample 2 (Layer Ia) and as low as Sample 16
(Layer IIb/III [see Figure 7, Table 3]). Thus the local extinction of this species must have occurred after 1220-1430 cal A.D. A single specimen of Nesopupa sp. was found in Sample 2 at this locality, as well as an apical fragment of an unidentified helicinid in Sample 4.

Land mollusk specimens examined here have been deposited in the malacology collections of the Bernice P. Bishop Museum, Honolulu, Hawai'i.

\section{RESULTS}

\section{SYSTEMATIC REVIEW}

\section{Family Helicinidae}

Unidentified helicinid.

A single apical fragment of a helicinid snail was recovered from Sample 4 at Locality 3. Although we are confident of the assignment to family, the fragmentary nature of this specimen precludes identification to generic level. Helicinids occur widely in the Pacific 
TABLE 3

Stratigraphy and Land Snail Fauna from Locality 3 (Square 1 of Steadman et al. [1994]), Anakena, Easter Island, Based on Sediment Samples Collected on 9-16 July 1991 by D.W.S.

\begin{tabular}{|c|c|c|c|c|c|c|c|c|}
\hline $\begin{array}{l}\text { Sample } \\
\text { No. }\end{array}$ & $\begin{array}{l}\text { Volume } \\
\left(\mathrm{cm}^{3}\right)\end{array}$ & $\begin{array}{l}\mathrm{DBD} \\
(\mathrm{cm})\end{array}$ & Sediment Type & Color (moist) & $\mathrm{Ha}$ & $\mathrm{Pv}$ & $\mathrm{N}$ & $\mathrm{Hel}$ \\
\hline 1 & 680 & $5-10$ & Med calc sand & 10 YR $5 / 4$ very pale brown & - & $\mathrm{A}$ & - & - \\
\hline 2 & 710 & $10-20$ & " & " & $\mathrm{R}$ & $\mathrm{A}$ & $\mathrm{R}$ & - \\
\hline 3 & 660 & $20-30$ & $"$ & $10 \mathrm{YR} 7 / 3$ very pale brown & - & $\mathrm{A}$ & - & - \\
\hline 4 & 680 & $30-40$ & Fine-med calc sand & " & $\overline{\mathrm{R}}$ & $\mathrm{A}$ & - & $\overline{\mathrm{R}}$ \\
\hline 5 & 690 & $40-50$ & " & $10 \mathrm{YR} 8 / 3$ very pale brown & $\mathrm{R}$ & $\mathrm{A}$ & - & - \\
\hline 6 & 700 & $50-60$ & $"$ & " & $\mathrm{R}$ & $\mathrm{A}$ & - & - \\
\hline 7 & 700 & $60-70$ & $"$ & $"$ & - & $\mathrm{A}$ & - & - \\
\hline 8 & 690 & $70-80$ & $"$ & $"$ & $\mathrm{R}$ & $\mathrm{A}$ & - & - \\
\hline 9 & 700 & $81 / 83-90$ & $"$ & $"$ & $\mathrm{R}$ & $\mathrm{A}$ & - & - \\
\hline 10 & 470 & $91 / 94-102 / 104$ & $"$ & $"$ & $\mathrm{R}$ & $\mathrm{R}$ & - & - \\
\hline 11 & 650 & $102 / 104-111 / 113$ & $\begin{array}{l}\text { Sl clayey, fine-med } \\
\text { calc sand }\end{array}$ & $"$ & $\mathrm{R}$ & $\mathrm{R}$ & - & - \\
\hline 12 & 660 & $111 / 113-121 / 124$ & " & $"$ & $\mathrm{C}$ & $\mathrm{A}$ & - & - \\
\hline 13 & 210 & $121 / 124-124 / 133$ & $\begin{array}{l}\text { Clayey, sl pebbly } \\
\text { fine-med calc sand }\end{array}$ & 10YR $7 / 2$ light gray & - & $\mathrm{C}$ & - & - \\
\hline 14 & 45 & 126 & Silty clay & 10YR 7/1-7/2 light gray & - & $\mathrm{R}$ & - & - \\
\hline 15 & 480 & $130-133$ & $\begin{array}{l}\text { Clayey, silty fine-- } \\
\text { med calc sand }\end{array}$ & $10 \mathrm{YR} 7 / 4$ very pale brown & - & $\mathrm{A}$ & - & - \\
\hline 16 & 510 & $124 / 133-127 / 134$ & " & $"$ & $\mathrm{R}$ & $\mathrm{A}$ & - & - \\
\hline 17 & 240 & $134-140$ & $\begin{array}{l}\text { Silty, sl sandy, sl } \\
\text { pebbly clay }\end{array}$ & 7.5YR 3/3 dark brown & - & $\mathrm{R}$ & - & - \\
\hline
\end{tabular}

Note: Each sample was processed in the laboratory through a nested set of five standard sieves of mesh sizes 12.5, 5.6, 2.0, 1.19, and $0.60 \mathrm{~mm}$. Abbreviations: calc, calcareous; DBD, depth below datum; med, medium grained; sl, slightly. Color data follow the Munsell Soil Color Charts. Snail abundance categories: A, abundant $(>20)$; C, common $(5-20)$; R, rare $(<5)$. Ha, Hotumatua anakenana; Pv, Pacificella variabilis; N, Nesopupa sp.; Hel, unidentified helicinid.

islands (Solem 1959) and would be expected to occur on any Polynesian high island supporting an indigenous land snail fauna.

\section{Family Achatinellidae}

\section{Genus Hotumatua Kirch, Christensen \& Steadman, n. gen.}

Diagnosis: Small Achatinellidae with the parietal lamella bladelike in adults, distinctly bifid in juveniles; columellar lamellae 3, subequal in adults, distinctly bifid in juveniles; palatal lamellae weakly developed and reduced to 1 or 2 in number in adults, as many as 5 in juveniles, the $2 \mathrm{nd}$ and $3 \mathrm{rd}$ of these discontinuously nodular or bladelike and generally stronger than others.

TYPE SPECIES: Hotumatua anakenana Kirch, Christensen \& Steadman, n. sp.

RANGE: Easter Island; extinct.
REMARKs: Suprageneric affinities within the Achatinellidae are most clearly evidenced in the morphology of the genitalia, so the position of Hotumatua within the family is speculative. Based on shell characters, the closest allies of Hotumatua are in the subfamilies Pitysinae and Tornatellininae. Although the bifid parietal lamella of Hotumatua is unique within the family, this condition is most closely approached in two genera of Pitysinae from Rapa, namely Pitys Mörch, 1837, and Lamellovum Pilsbry, 1910, in which the underside of the parietal lamella may be tuberculose or ribbed; discontinuous palatal lamellae are also present in some species. Multiple and/or discontinuous palatal lamellae also occur in several of the Pitysinae, such as Apopitys Cooke \& Kondo, 1960; Celticola Cooke \& Kondo, 1960; and Strobilus Anton, 1839, of Rapa, and Tubuaia Cooke \& Kondo, 1960, which occurs from Henderson, 


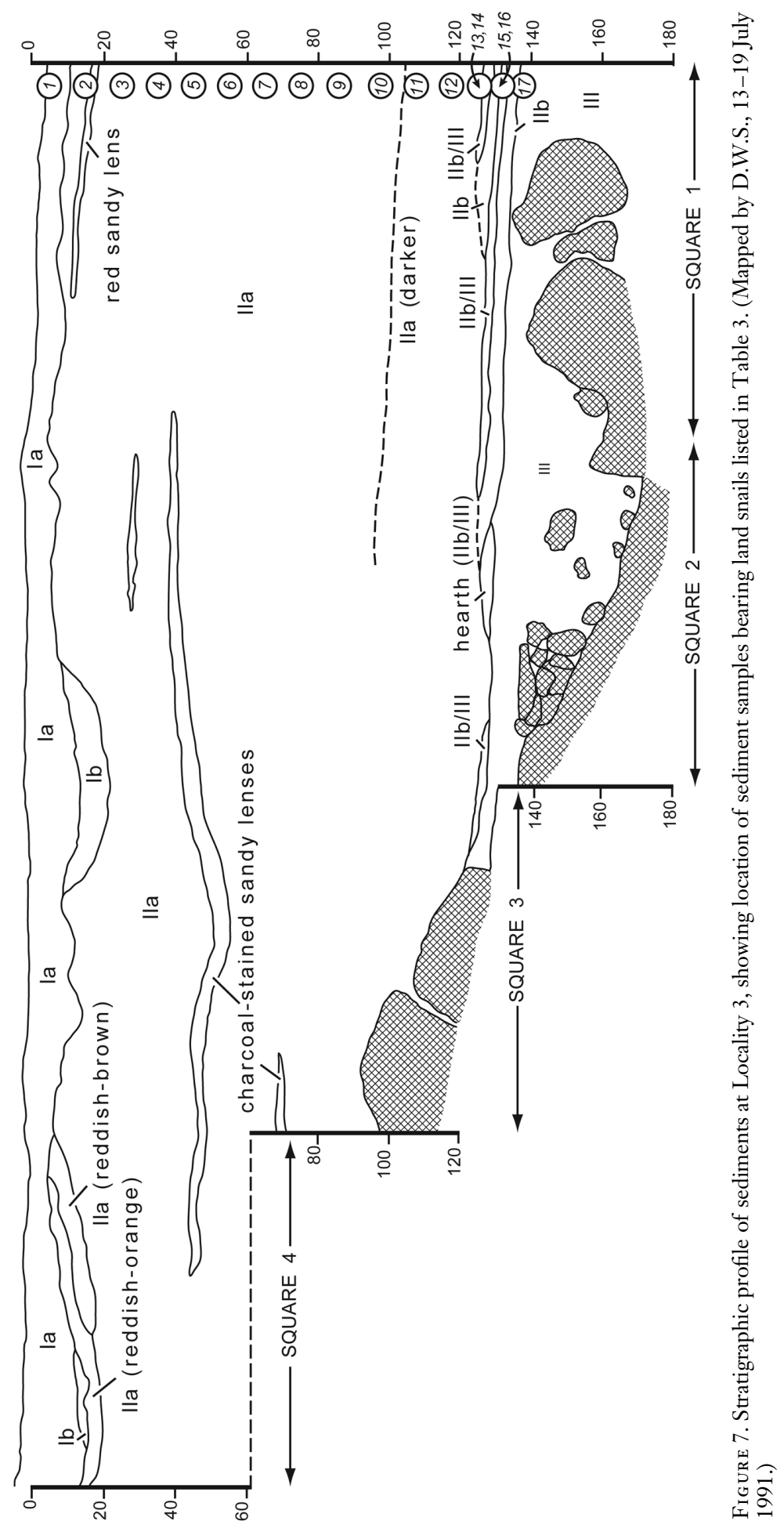


Pitcairn, and Mangareva to the Kermadecs. The triple armature of the columella is otherwise restricted to taxa from Rapa, where it is found in Pitys, Apopitys, one species of Strobilus, and some juvenile shells of Taitaa Cooke \& Kondo, 1960. Among the Tornatellininae of Juan Fernández, some species of Tornatellina Pfeiffer, 1842, show similarities to Hotumatua, as does the tekoulinine Tekoulina Solem, 1972, of Rarotonga, Cook Islands. Tekoulina, however, is much larger (adults to $9.1 \mathrm{~mm}$ in height) and has a simple parietal lamella and single palatal and columellar lamellae (Solem 1972). No members of these genera exhibit the unique suite of characters in their apertural dentition (especially the presence of a bifid parietal lamella) that is characteristic of Hotumatua.

eTYMology: In legend, Hotumatua was the king who led the immigrant Polynesians from their ancestral home of Maraerenga (Mangareva?) to Rapa Nui (Easter Island); Anakena Bay is the traditional site of his first landing (Routledge 1919).

\section{Hotumatua anakenana Kirch, Christensen \&} Steadman, n. sp.

Figures 8-9

DESCRIPTION: Adult shell weakly rimate, elongate conic, outline of spire slightly convex; whorls convex, sutures moderately impressed, sculpture of weak growth wrinkles; shell height ca. $4.2 \mathrm{~mm}$, diameter $2.0 \mathrm{~mm}$, whorl count unknown but estimated to be in excess of 7 (apical whorls missing in single adult paratype); parietal lamella high and bladelike; columellar lamellae 3, subequal, palatal lamellae 2, one of them (apparently corresponding to $3 \mathrm{rd}$ palatal lamella of juveniles) a low nodule, the other (4th palatal lamella of juveniles) a low weak ridge; a weak nodule, apparently not analogous to any of the palatal lamellae of juvenile shells, located just within peristome and immediately below 3rd columellar lamella; peristome somewhat damaged in single adult shell examined but apparently not expanded.

Juvenile shell imperforate; parietal lamella strong, extending out of view into aperture, distinctly bifid, its upper plait perpendicular

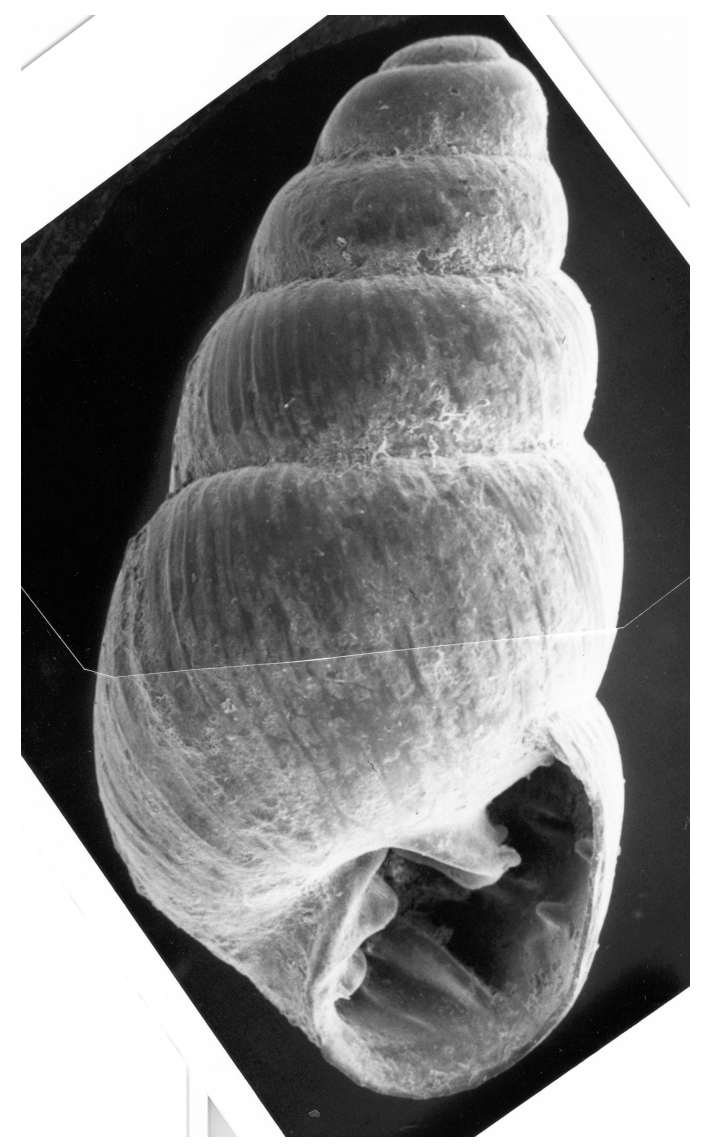

Figure 8. Hotumatua anakenana Kirch, Christensen \& Steadman, n. gen., n. sp. Holotype. врвм 8985. Shell height $1.9 \mathrm{~mm}$.

to shell axis, lower plait more prominent, strongly downturned within, parietal lamella becoming bladelike in older juveniles; 2nd columellar lamella usually more strongly developed than 1st and 3rd; palatal lamellae as many as 5 , more strongly developed in young juveniles, later becoming reduced; in specimens with well-developed palatal lamellae, the 1st (posterior) present as a single elongate nodule, 2 nd or 3rd discontinuous with several low nodules, 4th high and bladelike, 5th weak or absent. Measurements of three juvenile shells: врвм 207627, height $2.9 \mathrm{~mm}$, diameter $1.45 \mathrm{~mm}$, whorls 5-7/8; в Рвм 8985, height 2.6 $\mathrm{mm}$, diameter $1.4 \mathrm{~mm}$, whorls 5-1/4; врвм 


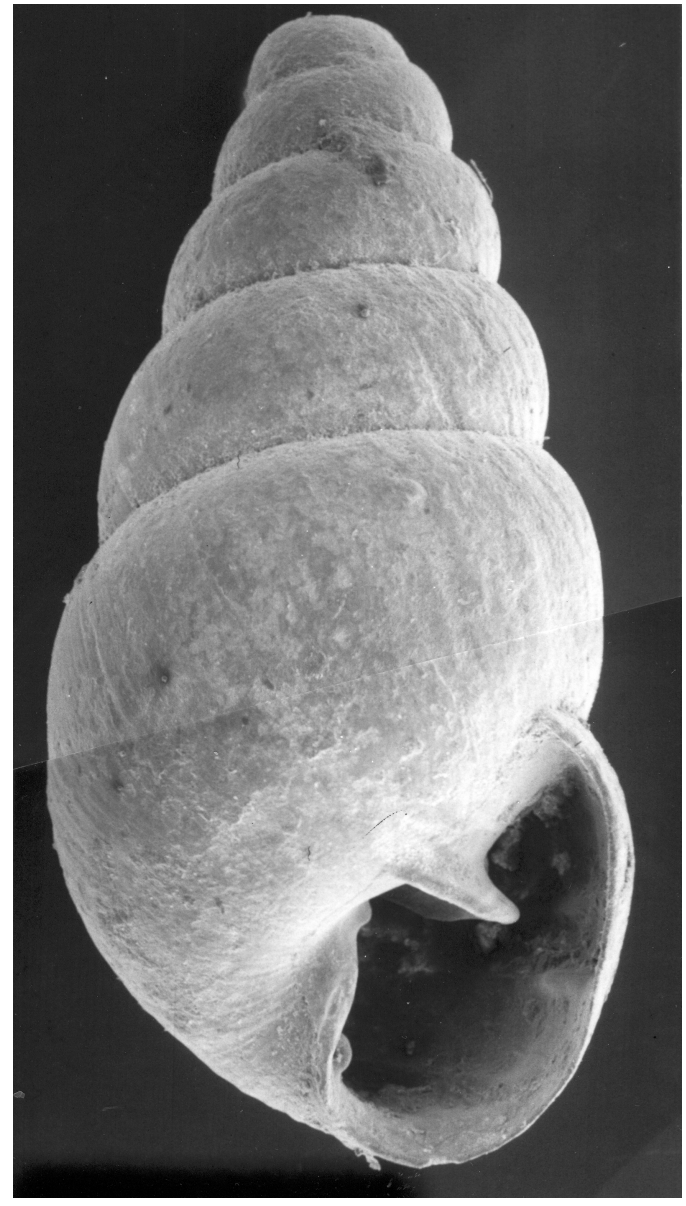

Figure 9. Hotumatua anakenana Kirch, Christensen \& Steadman, n. gen., n. sp. Paratype. врвм 207627. Shell height $2.9 \mathrm{~mm}$.

207590, height $1.9 \mathrm{~mm}$, diameter $1.1 \mathrm{~mm}$, whorls 4-1/8.

TYPE MATERIAL: Deposited in the malacology collection of the Bernice P. Bishop Museum, Honolulu, Hawai'i. Holotype: врвм 8985. Paratypes: врвм 207590 (1 specimen); врвм 207592 (1 specimen); врвм 207627 (1 specimen). Easter Island: Anakena Valley, Locality 2 (109 $\left.19^{\prime} 40^{\prime \prime} \mathrm{W}, 27^{\circ} 04^{\prime} 10^{\prime \prime} \mathrm{S}\right)$ : erosional exposure in streamcut near mouth of gully above sandy beach, in streamdeposited layer of brown clay overlain by $1-$ $2 \mathrm{~m}$ of calcareous dune sand. Patrick V. Kirch, 14 September 1984.
REMARKS: Collected with the type material were three additional shells clearly referable to Hotumatua but not certainly conspecific with $H$. anakenana; we do not include them among the type material of that species but mention them only to indicate that future workers may be able to document a greater range of intraspecific variation within $H$. anakenana than we now recognize or, conceivably, the presence of additional species of Hotumatua on the island. One of these (врвм 207589) is $3.9 \mathrm{~mm}$ in height, $1.6 \mathrm{~mm}$ in diameter, and has 7-3/8 whorls. Another specimen (вРвм 207591) is $3.3 \mathrm{~mm}$ in height, $1.8 \mathrm{~mm}$ in diameter, and has 6-1/4 whorls; the spire of this shell is straightly conical, not convex in outline as in other Hotumatua examined, and the growth wrinkles are stronger than in other specimens. Collection and study of more material is needed to determine whether additional species of Hotumatua are represented at the Anakena sites.

Specimens of Hotumatua collected in 1991 consist of columellar, palatal, or other nondiagnostic fragments that demonstrate the distinctive apertural armature of this genus and are thus unquestionably referable to it but cannot be assigned with any certainty to H. anakenana.

ETYMOLOGY: The species is named for its type locality, Anakena, on Easter Island.

nomenclatural note: Bahn and Flenley (1992:90) mentioned the presence of $\mathrm{Ho}_{0}$ tumatua anakenana on Easter Island by name (based on Flenley's access to an early manuscript version of this paper) but provided no description. Their use of this nomen nudum did not validate the name.

\section{Pacificella variabilis Odhner, 1922}

Specimens of $P$. variabilis were present in five samples in the upper part of Locality 2 (Table 2) and present in all samples throughout the Locality 3 column, often in abundance (Table 3). These specimens clearly establish the presence of $P$. variabilis on Easter Island during the period of Polynesian occupation. The geographic distribution of the species is from western Polynesia (Samoa, Tonga) throughout southeastern Polynesia, 
to Easter Island (Cooke and Kondo 1960, fig. 77), a pattern that led Cooke and Kondo (1960:165) to infer that it had been transported by "man's agency." The place of origin of $P$. variabilis within this area has been thought to be unknown, but Preece (1998) reported the presence of this species on Henderson Island before its settlement by Polynesians, indicating that it is indigenous to that island. He also suggested the possibility that $P$. variabilis as currently understood may include more than one species, a question we do not attempt to resolve here.

\section{Family Pupillidae}

\section{Nesopupa sp.}

A single specimen of an unidentified species of Nesopupa Pilsbry, 1900, was found in Sample 2 at Locality 3. Species of Nesopupa are widely distributed in Polynesia and occur also in the Galápagos, in the Cocos Islands off the Pacific coast of Costa Rica, and in South America (Pilsbry 1920-1921, Vagvolgyi 1974, Altena 1975), so their presence on Easter Island is not unexpected.

\section{DISCUSSION}

The samples from three stratigraphic contexts at Anakena confirm that Easter Island formerly supported an endemic molluscan fauna, comprising taxa in at least three families. Most notable is the discovery of an endemic genus of the relict Pacific family Achatinellidae, but the material reported here also documents the presence of an unidentified species of Helicinidae and an unidentified species of Nesopupa. The confused state of the taxonomy of these groups and the paucity of the material examined here prevent further analysis of these Easter Island snails.

Our land snail samples represent a temporal sequence of some interest. The samples from Localities 2 and 3 date to an early phase after Polynesian colonization, whereas those from Locality 1 are from a later period after construction of Ahu Naunau (ca. 1300 A.D. or younger). Thus the snail samples from these three nearby localities document the extinction of an endemic molluscan fauna and its replacement with a fauna composed of synanthropic or human-transported (anthropochoric) species, especially Pacificella variabilis and probably also Allopeas gracile. Given the palynological evidence for deforestation following Polynesian settlement of Easter Island (Bahn and Flenley 1992), it is likely that this extinction/replacement sequence was a direct corollary of human-induced habitat alteration. The sediment sequence at each land snail locality suggests clearance of vegetation and consequent greater erosion within the Anakena drainage basin.

Future paleoenvironmental studies on Easter Island should continue to enhance our understanding of this island's former endemic biota. For now, we know that an endemic genus of Achatinellidae was present, with its probable closest relatives elsewhere in Polynesia rather than in the Neotropical region. Our collections document the presence on Easter Island of unidentified species of the families Helicinidae and Pupillidae. Other families with endemic species in southeastern Polynesia, and which therefore might have occurred on Easter Island, include the Hydrocenidae, Assimineidae, Partulidae, Endodontidae, and Helicarionidae. The Succineidae and Charopidae of Juan Fernández are apparently of American origin (Tillier 1981, Solem 1983), but because endemic species of both these families do occur in Polynesia and elsewhere in the Pacific, their presence on Easter Island would not be unexpected.

The extinction of land snails on Easter Island adds another example of the humaninduced changes in Pacific island ecosystems that began with colonization by prehistoric peoples and continues today. It is well known that many Pacific islands once supported highly diverse indigenous terrestrial molluscan faunas that have suffered substantial losses and replacement by introduced species after prehistoric and historic human-induced environmental change (e.g., Cooke 1935:41, Christensen and Kirch 1981, 1986, Chambers and Steadman 1986, Hopper and Smith 1992, 
Bauman 1996, Burney et al. 2001, Cowie 2001a,b, Cowie and Cook 2001, Cowie and Robinson 2003, Cowie and Grant-Mackie 2004, Lydeard et al. 2004).

Polynesians may have colonized Easter Island as early as ca. 900-1000 cal A.D., perhaps from Mangareva (Green 1998), where recent excavations have established that Polynesians were present at that time (Conte and Kirch 2004). A recent analysis of Easter Island's archaeological chronology revised this estimate to ca. 1100-1200 cal A.D. (Hunt and Lipo 2006). Regardless of the precise time of first human arrival, by the time of European contact the Easter Island environment had been radically altered through several centuries of intensive land use, including forest clearance and development of an intensive dryland agricultural system (Kirch 1984, Orliac 2000, 2003, Mann et al. 2003, Hunt 2007). One consequence of this sequence of human-induced landscape change was the devastating loss of indigenous and endemic terrestrial taxa, which we now know to have included plants (such as the endemic palm Paschalococos disperta), land and seabirds (Steadman 2006), and land snails. The agents and processes of such environmental change remain a matter of debate (e.g., Hunt 2006) but probably included both direct human activities such as forest clearance for horticulture along with predation by anthropogenic alien species such as the Polynesian rat, Rattus exulans. However the debate over causation is ultimately resolved, it is increasingly clear that the cultural and natural histories of this most-isolated island were intimately intertwined.

\section{ACKNOWLEDGMENTS}

P.V.K. and D.W.S. thank Claudio Cristino F., then Director of the Instituto de Estudios de Isla de Pascua, Gustav Paulay, and Patricia Vargas C. for logistical and professional assistance and collaboration in the field. Research permits were provided by the Consejo para Monumentos, Santiago. Field assistance was also kindly provided by the staffs of Museo de la Isla de Pascua and Parque Nacional de la Isla de Pascua, particularly Marcos Rausch. For comments on the manuscript, we thank G. Paulay, P. Vargas C., and two anonymous reviewers.

\section{Literature Cited}

Abdou, A., and P. Bouchet. 2000. Nouveaux gastéropodes Endodontidae et Punctidae (Mollusca, Pulmonata) récemment éteints de l'archipel des Gambier (Polynésie). Zoosystema 22:689-707.

Altena, C. O. van R. 1975. Land Gastropoda of Suriname, with the description of a new species of Nesopupa. Basteria 39:29-50.

Bahn, P., and J. R. Flenley. 1992. Easter Island, earth island. Thames and Hudson, London.

Bauman, S. 1996. Diversity and decline of land snails on Rota, Mariana Islands. Am. Malacol. Bull. 12:13-27.

Bouchet, P., and A. Abdou. 2001. Recent extinct land snails (Euconulidae) from the Gambier Islands with remarkable apertural barriers. Pac. Sci. 55:121-127. 2003. Endemic land snails from the Pacific Islands and the museum record: Documenting and dating the extinction of the terrestrial Assimineidae of the Gambier Islands. J. Molluscan Stud. 69:165170.

Boyko, C. B., and J. R. Cordeiro. 2001. The terrestrial Mollusca of Easter Island (Gastropoda, Pulmonata). Basteria 65:17-25.

Burney, D. A., H. F. James, L. P. Burney, S. L. Olson, W. Kikuchi, W. L. Wagner, M. Burney, D. McCloskey, D. Kikuchi, F. V. Grady, R. Gage II, and R. Nishek. 2001. Fossil evidence for a diverse biota from Kaua' $i$ and its transformation since human arrival. Ecol. Monogr. 71:615-641.

Chambers, S. M. 1991. Biogeography of Galápagos land snails. Pages 307-325 in M. J. James, ed. Galápagos marine invertebrates: Taxonomy, biogeography, and evolution in Darwin's islands. Plenum Press, New York.

Chambers, S. M., and D. W. Steadman. 1986. Holocene terrestrial gastropod faunas from 
Isla Santa Cruz and Isla Floreana, Galápagos: Evidence for late Holocene declines. Trans. San Diego Soc. Nat. Hist. 21:89110.

Christensen, C. C., and P. V. Kirch. 1981. Nonmarine mollusks from archaeological sites on Tikopia, southeastern Solomon Islands. Pac. Sci. 35:75-88.

1986. Nonmarine mollusks and ecological change at Barbers Point, O'ahu, Hawai'i. Bishop Mus. Occas. Pap. 26:5280.

Conte, E., and P. V. Kirch, eds. 2004. Archaeological investigations in the Mangareva Islands (Gambier Archipelago), French Polynesia. Contribution No. 62. Archaeological Research Facility, University of California, Berkeley.

Cooke, C. M., Jr. 1935. Mangarevan Expedition: Report of C. Montague Cooke, Jr. Pages 36-56 in H. E. Gregory, Report of the Director for 1934. Bernice P. Bishop Mus. Bull. 133.

Cooke, C. M., Jr., and Y. Kondo. 1960. Revision of Tornatellinidae and Achatinellidae (Gastropoda, Pulmonata). Bernice P. Bishop Mus. Bull. 221:1-303.

Cowie, R. H. 2001a. Decline and homogenization of Pacific faunas: The land snails of American Samoa. Biol. Conserv. 99:207222.

. 2001b. Invertebrate invasions on $\mathrm{Pa}$ cific islands and the replacement of unique native faunas: A synthesis of the land and freshwater snails. Biol. Invasions 3:119_ 136.

Cowie, R. H., and R. P. Cook. 2001. Extinction or survival: Partulid tree snails in American Samoa. Biodivers. Conserv. 10:143-159.

Cowie, R. H., N. L. Evenhuis, and C. C. Christensen. 1995. Catalog of the native land and freshwater molluscs of the $\mathrm{Ha}$ waiian Islands. Backhuys Publishers, Leiden.

Cowie, R. H., and J. A. Grant-Mackie. 2004. Land snail fauna of Mé Auré Cave (WMD007), Moindou, New Caledonia: Human introductions and faunal change. Pac. Sci. 58:447-460.

Cowie, R. H., and A. C. Robinson. 2003. The decline of native Pacific island faunas: Changes in status of the land snails of Samoa through the 20th century. Biol. Conserv. 110:55-65.

Dall, W. H. 1908. Reports on the scientific results of the expedition to the eastern tropical Pacific, in charge of Alexander Agassiz, by the U.S. Fish Commission steamer "Albatross," from October, 1904 to March, 1905, Lieut.-Commander L. M. Garrett, U.S.N., commanding. XIV. The Mollusca and Brachiopoda. Bull. Mus. Comp. Zool. 43:205-487.

Dransfield, J., J. R. Flenley, S. M. King, D. D. Harkness, and S. Rapu. 1984. A recently extinct palm from Easter Island. Nature (Lond.) 312:750-752.

Falkner, G., T. E. J. Ripken, and M. Falkner. 2002. Mollusques Continentaux de France. Liste de Référence annotée et Bibliographie. Patrimoines naturels, 52. Muséum National d'Histoire Naturelle, Paris, France.

Flenley, J. R. 1979. Stratigraphic evidence of environmental change on Easter Island. Asian Perspect. 22:33-40.

Flenley, J. R., and B. Bahn. 2002. The enigmas of Easter Island. Oxford University Press, Oxford, United Kingdom.

Flenley, J. R., and S. M. King. 1984. Late Quaternary pollen records from Easter Island. Nature (Lond.) 307:47-50.

Flenley, J. R., S. M. King, J. Jackson, C. Chew, J. T. Teller, and M. E. Prentice. 1991. The late Quaternary vegetational and climatic history of Easter Island. J. Quat. Sci. 6:85-115.

Green, R. C. 1998. Rapanui origins prior to European contact: The view from eastern Polynesia. Pages 87-110 in P. Vargas, ed. Easter Island and East Polynesian prehistory. Instituto de Estudios Isla de Pascua, Universidad de Chile, Santiago.

Holloway, J. D. 1990. The Lepidoptera of Easter, Pitcairn and Henderson islands. J. Nat. Hist. 24:719-729.

Hopper, D. R., and B. D. Smith. 1992. Status of tree snails (Gastropoda: Partulidae) on Guam, with a resurvey of sites collected by H. E. Crampton in 1920. Pac. Sci. 46:77-85. 
Hunt, T. L. 2006. Rethinking the fall of Easter Island. Am. Sci. 94:412-419.

2007. Rethinking Easter Island's ecological catastrophe. J. Archaeol. Sci. 34:485-502.

Hunt, T. L., and C. P. Lipo. 2006. Late colonization of Easter Island. Science (Washington, D.C.) 311:1603-1606.

Johnson, A. W., W. R. Millie, and G. Moffett. 1970. Notes on the birds of Easter Island. Ibis 112:532-538.

Kirch, P. V. 1984. The evolution of the Polynesian chiefdoms. Cambridge University Press, Cambridge, United Kingdom.

Kondo, Y. 1962. The genus Tubuaia: Pulmonata, Achatinellidae. Bernice P. Bishop Mus. Bull. 224:1-49.

Lydeard, C., S. A. Clark, K. E. Perez, R. H. Cowie, W. F. Ponder, A. E. Bogan, P. Bouchet, O. Gargominy, K. S. Cummings, T. J. Frest, D. G. Herbert, R. Hershler, B. Roth, M. Seddon, E. E. Strong, and F. G. Thompson. 2004. The global decline of nonmarine mollusks. BioScience 54:321330.

Mann, D., J. Chase, J. Edwards, R. Beck, R. Reanier, and M. Mass. 2003. Prehistoric destruction of the primeval soils and vegetation of Rapa Nui (Isla de Pascua, Easter Island). Pages 133-153 in J. Loret and J. T. Tanacredi, eds. Easter Island: Scientific exploration in the world's environmental problems in microcosm. Kluwer Academic/Plenum, New York.

Martinsson-Wallin, H., and S. J. Crockford. 2001. Early settlement of Rapa Nui (Easter Island). Asian Perspect. 40:244-278.

Naranjo-Garcia, E., and C. C. Appleton. 1998. Dos nuevos registros demoluscos terrestres introducidos en la Isla de Pascua, Chile. Biociencias 6:119-124.

Odhner, N. J. 1922. Mollusca from Juan Fernandez and Easter Island. Pages 219-254 in C. Skottsberg, ed. The natural history of Juan Fernandez and Easter Island. Vol. 3. Almquist and Wiksells BoktryckeriA.-B, Uppsala.

. 1963. Ambrosiella kuscheli n. gen., n. sp., a tornatellinid land shell from San Ambrosio Island. Proc. Malacol. Soc. Lond. 35:207-209.
Orliac, C. 2000. The woody vegetation of Easter Island between the early 14th and the mid-17th centuries A.D. Pages 211220 in C. Stevenson and W. Ayres, eds. Easter Island archaeology: Research on early Rapanui culture. Easter Island Foundation, Los Osos. 2003. Ligneux et palmiers de l'île de Paques du XIeme au XVIIeme siècle de notre ère. Pages 184-199 in C. Orliac, ed. Archéologie en Océanie Insulaire: Peuplement, societes et paysages. Editions Artcom, Paris.

Pilsbry, H. A. 1920-1921. Manual of Conchology. 2nd ser. Vol. 26. Pupillidae (Vertigininae, Pupillinae). Academy of Natural Sciences, Philadelphia.

Pilsbry, H. A., and C. M. Cooke Jr. 1933. Notes on the land snail family Tornatellinidae. Nautilus 47:59-62.

Preece, R. C. 1995. Systematic review of the land snails of the Pitcairn Islands. Biol. J. Linn. Soc. 56:273-407.

- 1998. Impact of early Polynesian occupation on the land snail fauna of Henderson Island, Pitcairn Group (South $\mathrm{Pa}$ cific). Philos. Trans. R. Soc. Lond. B Biol. Sci. 353:347-368.

Rolett, B. V. 1992. Faunal extinctions and depletions linked with prehistory and environmental change in the Marquesas Islands (French Polynesia). J. Polynesian Soc. 101:86-94.

Roth, B. 1986. Note on three European land mollusks introduced to California. Bull. South. Calif. Acad. Sci. 85:22-28.

1987. Punctum pusillum (Gastropoda: Pulmonata: Punctidae) - a correction. Veliger 30:95-96.

Routledge, Mrs. S. 1919. The mystery of Easter Island: The story of an expedition. Sifton, Praed \& Co., London.

Skjolsvold, A. 1994. Archaeological investigations at Anakena, Easter Island. Kon-Tiki Mus. Occas. Pap. 3:5-121.

Skottsberg, C. 1956. Derivation of the flora and fauna of Juan Fernandez and Easter Island. Pages 193-438 in C. Skottsberg, ed. The natural history of Juan Fernandez and Easter Island. Vol. 3. Almquist and Wiksells Boktryckeri-A.-B, Uppsala. 
Solem, A. 1959. Systematics and zoogeography of the land and fresh-water Mollusca of the New Hebrides. Fieldiana Zool. 43:1-359, pl. 1-34.

- 1972. Tekoulina, a new viviparous tornatellinid land snail from Rarotonga, Cook Islands. Proc. Malacol. Soc. Lond. 40:93-114.

1973. Island size and species diversity in Pacific island land snails. Malacologia 14:397-400.

1976. Endodontoid land snails from Pacific islands (Mollusca: Pulmonata: Sigmurethra). Part I. Family Endodontidae. Field Museum of Natural History, Chicago. - 1981. Land snail biogeography: A true snail's pace of change. Pages 197237 in G. Nelson and D. E. Rosen, eds. Vicariance biogeography: A critique. Columbia University Press, New York. 1983. Endodontoid land snails from Pacific islands (Mollusca: Pulmonata: Sigmurethra). Part II. Families Punctidae and Charopidae, zoogeography. Field Museum of Natural History, Chicago.

Steadman, D. W. 1995. Prehistoric extinc- tions of Pacific island birds: Biodiversity meets zooarchaeology. Science (Washington, D.C.) 267:1123-1131.

. 2006. Extinction and biogeography of tropical Pacific birds. University of Chicago Press, Chicago.

Steadman, D. W., C. Cristino F., and P. Vargas C. 1994. Stratigraphy, chronology, and cultural context of an early faunal assemblage from Easter Island. Asian Perspect. 33:79-96.

Tillier, S. 1981. South American and Juan Fernandez slugs (Pulmonata). J. Molluscan Stud. 47:125-146.

Vagvolgyi, J. 1974. Nesopupa galapagensis, a new Indo-Pacific element in the land snail fauna of the Galapagos Islands (Pulmonata: Vertiginidae). Nautilus 88: 86-89.

Waldén, H. W. 1961. On the variation, nomenclature, distribution and taxonomic position of Limax (Lehmannia) valentianus Férussac (Gastropoda, Pulmonata). Ark. Zool. 15:71-94.

Zizka, G. 1991. Flowering plants of Easter Island. Palmarum Hortus Francofurtensis $3: 1-108$. 